\title{
$\mathrm{B} 220$ 複数の蓄熱器を持つ熱音響エンジン
}

\section{Thermoacoustic Engine with Multiple Regenerators}

\author{
$\bigcirc$ 長谷川 大地（東北大） \\ 正 琵琶 哲志（東北大）
}

\author{
Tetsushi BIWA and Daichi HASEGAWA, Tohoku University, Aramaki 6, Aoba-ku, Sendai
}

\begin{abstract}
How much can we lower the onset temperature ratio (OTR) that is necessary for a thermoacoustic engine to start? We tried to answer this question by installing a secondary regenerator into a traveling wave engine consisting of a looped tube and a branch resonator. Factors governing the OTR were experimentally studied through measurements of the quality factor at various temperature ratios. It was found that the installation of the secondary regenerator at a suitable position drastically enhanced thermoacoustic effects while introducing a slight damping to the system. As a result, the OTR of the present thermoacoustic engine was decreased from 1.76 to 1.19 , when the total number of regenerators was increased to 5 .
\end{abstract}

Key Words: Thermoacoustic engine, Onset temperature ratio, Quality factor measurement, Multiple regenerators

\section{1.はじめに}

1999 年, Backhaus ら (1)は可動部の全くない新しいタイプ の外燃機関でカルノ一効率の $42 \%$ を実現したという報告を 行った。これは通常の熱機関と同等の効率である.この外 燃機関はループ状の管部分, 共鳴管状の部分そして流路半 径 $r_{0}$ の蓄熱器(狭い流路の集合体)から構成されており構造 が非常に単純である，蓄熱器の両端を高温熱交換器, 低温 熱交換器で挟み，その両端の温度をそれぞれ $T_{H}, T_{C}$ とす ると温度比 $T_{H} / T_{C}$ がある臨界值を超えた時, 管内の流体が ひとりでに気柱振動(熱音響自励振動)を始める.このとき の周波数は共鳴管部分の先端に流速の腹，ループ管部分に 圧力の腹が位置するような管全長の $1 / 4$ 波長のモード(2)に 対応する.

その自励振動は蓄熱器内で起こるエネルギ一変換で維持 される。蓄熱器内で往復運動する流体要素が圧縮, 加熱, 膨張，冷却といったスターリングサイクルに似た熱力学的 サイクルを実行し，熱から音波へのエネルギー変換を行う からである．得られる出力仕事は共鳴管を通して音波の形 で出力される. $2.3 \mathrm{~kW}$ の入力に対して実に $700 \mathrm{~W}$ の音響 出力が報告されている。

彼らが開発した装置は熱音響スターリングエンジンと呼 ばれ，可動部がないためメンテナンスフリーであること， 外燃機関であるため熱源を選ばないことが利点のエンジン である。しかし，彼らの装置では高いカルノ一効率比は実 現したものの，その時の温度比は $T_{H} / T_{C}=3.46$ であり， $T_{H}$ は $998 \mathrm{~K}$ とかなり高温である。熱音響エンジンの動作開始 温度(発振臨界温度比)を小さくできれば広い範囲の温度域 でこの新しいエンジンを利用することが可能となるだろう。 我々はループ管部分に第二蓄熱器を設置するという方法で 発振臨界温度比を小さくしようと試みた。

\section{2. 発振臨界温度比}

熱音響エンジンの発振臨界温度比は安定曲線として角振 動数 $\omega$ と熱緩和時間 $\tau$ の積 $\omega \tau$ で整理できることが知られ ている。 $\tau$ は熱緩和時間で $r_{0}$ と熱拡散係数 $\alpha$ を用いて $\tau=r_{0}{ }_{0} / 2 \alpha$ と表される. Fig. 1 に今まで報告された主な安 定曲線を示す．安定曲線上部ではエンジンが自励振動して いる状態, 下部では自励振動していない状態である. 図中 の白抜きの丸，黑抜きの丸はそれぞれ上田らによるループ

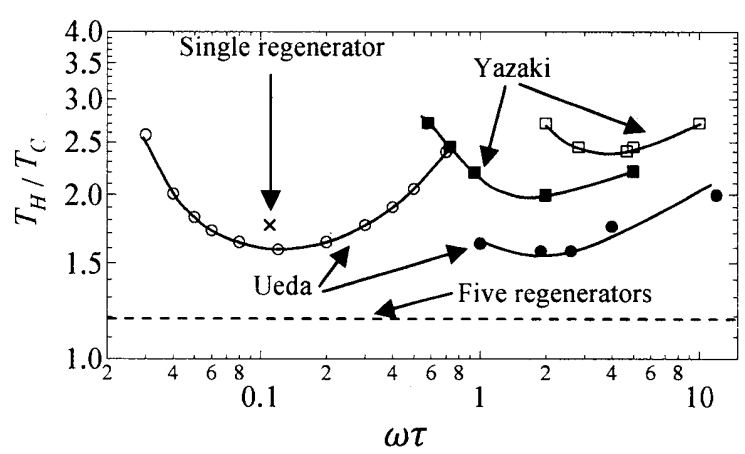

Fig. 1 Onset temperature ratio of the thermoacoustic engines.

管と共鳴管を組み合わせたタイプの計算結果 ${ }^{(3)}$, ループ管 タイプの実験結果 ${ }^{(4)}$ である．白抜きの四角，黒抜きの四角 はそれぞれ矢崎らによる共鳴管タイプ，ループ管タイプの 実験結果 ${ }^{(5)}$ である. 今回の我々の結果では $T_{H} / T_{C}=1.76$ の 点から点線で示した直線の位置 $T_{H} / T_{C}=1.19$ まで発振臨 界温度比を小さくすることができた。これは今まで報告さ れてきたどのタイプの熱音響エンジンよりもはるかに低い 発振臨界温度比であることが分かる。

\section{3. 実験装置}

Fig. 2 に我々が対象とした熱音響エンジンを示す. エン ジンは全長 $1500 \mathrm{~mm}$ のループ管部分, 全長 $1450 \mathrm{~mm}$ の共 鳴管部分, 容量が 201 のタンク, $r_{0}=0.15 \mathrm{~mm}(\omega \tau=0.11)$ の蓄熱器から構成されており, Backhausらの装置とほぼ同 様の形状をしている. 発振機と接続されたスピーカーは T 字型の配管パーツを介してループ管部分に接続した。発振 臨界温度比 $T_{H} / T_{C}=1.76(\Delta T=226 \mathrm{~K})$ の時 $31 \mathrm{~Hz}$ で自励振 動を開始する。ループ管内にはループ管の全長で無次元化 した $L$ 軸を反時䚺周りにとった。黒く塗りつぶした位置は 第二蓄熱器の設置位置である. 実験では一貫して $T_{C}$ は冷却 水循環装置を用いて $298 \mathrm{~K}$ に保った。図では加振用スピー カーを取り付けてあるが，奏際に発振臨界温度比を確認す る際はT字型パーツと共にスピーカーを外しその部分にエ ルボーを取り付けて実験を行った。 


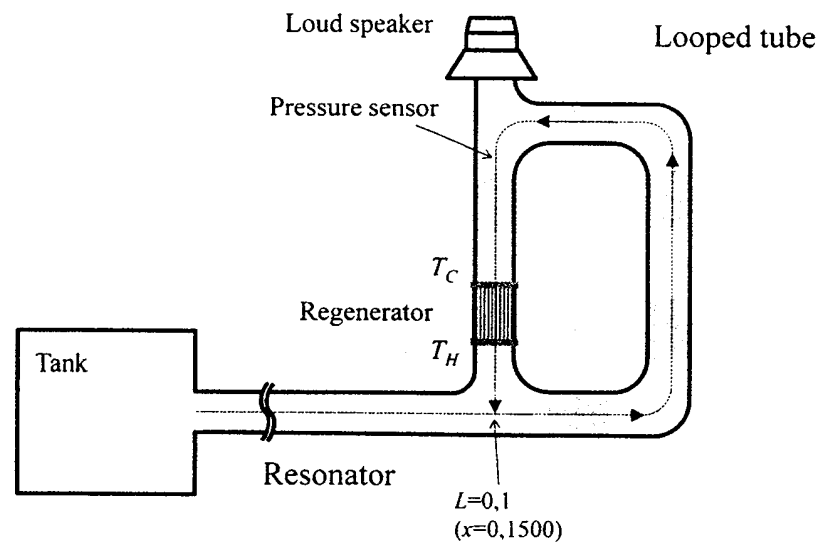

Fig. 2 A schematic illustration of the thermoacoustic engine.

\section{4. 実験方法}

実験では第二蓄熱器の流路半径 $\mathrm{r}_{0}$, 第二蓄熱器の設置位 置 $L$, そして温度比 $T_{H} / T_{C}$ を変化させ自励振動前の $Q$ 值 に着目することで発振臨界温度比を調べた， $Q$ 值の算出は 管内を loud speaker で連続的に加振し圧力センサーでモニ ターした圧力を用いて共鳴曲線を求め, その半值幅とピー ク周波数を求めることで行った。

\section{$4.1 \quad 1 / Q$ と $T_{H} / T_{C}$ の関係}

Fig. 3 に実験で得た $1 / Q$ と $T_{H} / T_{C}$ の関係を示す. 対象と する熱音響エンジン（ループ管内には蓄熱器は一つ）の

場合で, 点線は実験值の外挿線である.

$1 / Q$ は系に蓄えられるエネルギー $E_{S}$, 系の単位時間当た りの散逸エネルギ一 $\dot{E}$, 角振動数 $\omega$ を用いて式 $(*)$ のよ うに表すことができる。更に $\dot{E}$ は管での散逸エネルギー $\dot{E}_{\text {Pipe }}$, 蓄熱器での散逸エネルギー $\dot{E}_{\text {Reg. }}$, 蓄熱器に温度勾 配を与えたことで生成される熱音響効果による生成エネル ギー $\dot{E}_{\Delta T}$ に分けることができる.

$$
\frac{1}{Q}=\frac{\dot{E}}{\omega E_{S}}=\frac{\dot{E}_{\text {Pipe }}+\dot{E}_{\text {Reg. }}-\dot{E}_{\Delta T}}{\omega E_{S}}
$$

$T_{H} / T_{C}=1$ の時, 蓄熱器内でエネルギ一変換が起こって いない状態 $\left(\dot{E}_{\Delta T}=0\right)$ なので外挿線の $y$ 切片は熱音響エン ジンの室温での散逸の程度を表すと言える. $T_{H} / T_{C}$ を大き くすると $1 / Q$ が減少している.これは $T_{H} / T_{C}$ を大きくする ことで $\dot{E}$ が減少していることを意味し， $\dot{E}_{\Delta T}$ が $\dot{E}_{\text {pipe }}+$ $\dot{E}_{\text {Reg. }}$ を補った結果である.このことから, 外挿線の傾きは蓄熱 器内でのエネルギ一変換の活発さを表していると言える. 更に $T_{H} / T_{C}$ を大きくすると $T_{H} / T_{C}=1.78$ で $1 / Q \rightarrow 0$ となる. このと き $\dot{E}_{\Delta T}$ が $\dot{E}_{\text {pipe }}+\dot{E}_{R e g}$. と釣り合っている状態である. 実際, $T_{H} / T_{C}=1.76(\Delta T=226 \mathrm{~K})$ での自励振動の開始を確認したの で, 系が発振臨界温度比に達するとき $1 / Q \rightarrow 0$ となることがわ かる. 外挿線の $y$ 切片が小さくて傾きが急ならば発振臨界 温度は小さくなるので，この二つの要素に着目し第二蓄熱 器の $r_{0}, L$ を決定した.

\section{5. 実験結果}

Fig. 4 に対象とした熱音響エンジンに第二蓄熱器を設置 した場合の $1 / Q$ と $T_{H} / T_{C}$ の関係を示す．点線は Fig.3 と同 様に実験值の外挿線である. 今回の実験の $r_{0}, L$ の範囲内 では発振臨界温度比は1/Qの y 切片よりも傾きに大きく

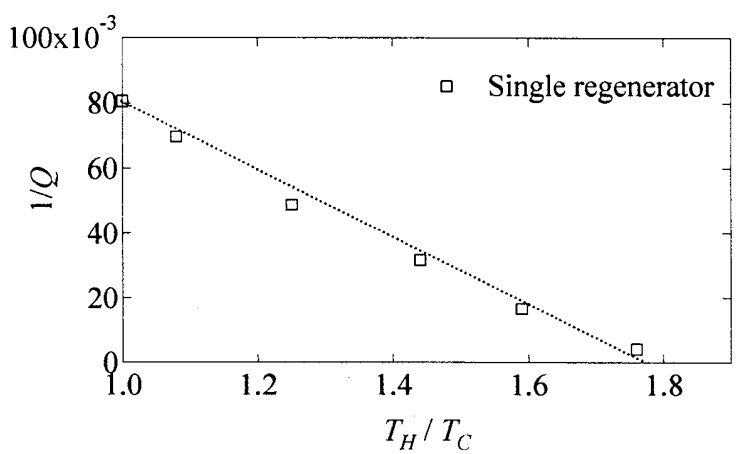

Fig. $31 / Q$ as a function of the $T_{H} / T_{C}$ of the present engine with a single regenerator.

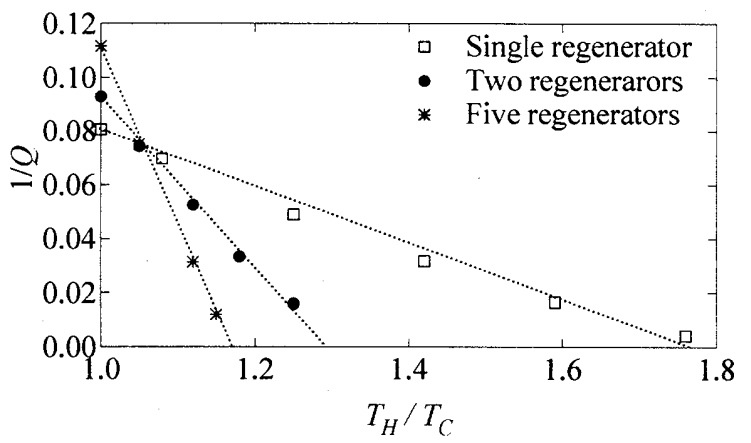

Fig. $41 / Q$ as a function of the $T_{H} / T_{C}$ of the present study.

依存していたので, 第二蓄熱器の $r_{0}, L$ はループ管内に第二 蓄熱器を設置した時, $1 / Q$ の傾きが最大となるものを選んだ.

対象とした熱音響エンジンと比較して第二蓄熱器を設置 した場合では外挿線の $y$ 切片の值は大きくなるものの, 傾 きは約三倍となり $T_{H} / T_{C}=1.30$ で $1 / Q \rightarrow 0$ になると読み取 れる. 実際, 実験では $T_{H} / T_{C}=1.34(\Delta T=100 \mathrm{~K})$ での自励 振動の開始を確認した. 第二蓄熱器をループ管部分に設置 するという方法が発振臨界を小さくすることに有効であっ たので, 更に蓄熱器を追加し合計五つ設置すると, 他の二 つの場合と比較して傾きは著しく大きくなり遂には $T_{H} / T_{C}=1.19(\Delta T=57 \mathrm{~K})$ での自励振動の開始を確認した.

\section{6. まとめ}

・臨界温度比 $T_{H} / T_{C}=1.76(\Delta T=226 \mathrm{~K})$ の熱音響エンジンの ループ管部分に蓄熱器を複数個追加することで発振臨界温 度比を $T_{H} / T_{C}=1.19(\Delta T=56 \mathrm{~K})$ まで小さくすることができ た。

\section{参考文献}

(1)S. Backhaus and G. W. Swift, Nature, 339 (1999), 335.

(2)Y. Ueda, et al., Appl. Phys. Lett. , 81 (2002), 5252.

(3)S. Nagata and Y. Ueda, 低温工学, 43 (2008), 561.

(4)Y. Ueda and C. Kato, J. Acoust. Am., 124 (2008), 851.

(5)T. Yazaki, et al., Phys. Rev. Lett. , 81 (1998), 3128. 